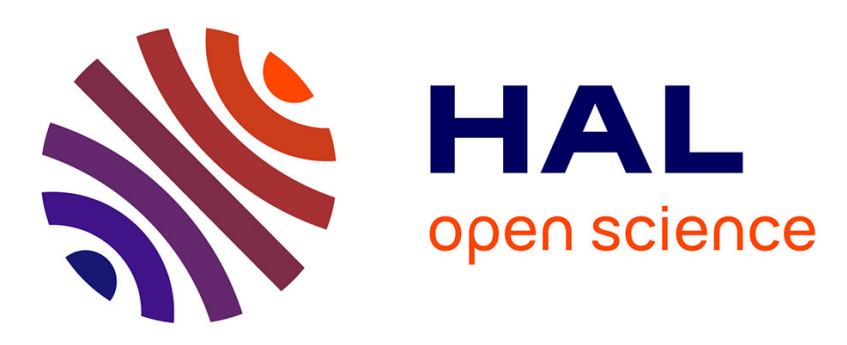

\title{
The bionomics of Anopheles funestus and its role in malaria transmission in a forested area of southern Cameroon
}

\author{
Lucien Manga, Jean-Claude Toto, Gilbert Le Goff, Jacques Brunhes
}

\section{- To cite this version:}

Lucien Manga, Jean-Claude Toto, Gilbert Le Goff, Jacques Brunhes. The bionomics of Anopheles funestus and its role in malaria transmission in a forested area of southern Cameroon. Transactions of The Royal Society of Tropical Medicine and Hygiene, 1997, 91 (4), pp.387-388. 10.1016/s00359203(97)90249-2 . hal-03363165

\section{HAL Id: hal-03363165 https://hal.science/hal-03363165}

Submitted on 5 Oct 2021

HAL is a multi-disciplinary open access archive for the deposit and dissemination of scientific research documents, whether they are published or not. The documents may come from teaching and research institutions in France or abroad, or from public or private research centers.
L'archive ouverte pluridisciplinaire HAL, est destinée au dépôt et à la diffusion de documents scientifiques de niveau recherche, publiés ou non, émanant des établissements d'enseignement et de recherche français ou étrangers, des laboratoires publics ou privés. 


\section{Short Report}

\section{The bionomics of Anopheles funestus and its role in malaria transmission in a forested area of southern Cameroon}

Lucien Manga ${ }^{1}$, Jean C. Toto ${ }^{1}$, Gilbert/Le Goff ${ }^{2}$ and Jacques/Brunhes ${ }^{2}{ }^{1}$ Malaria Department, OCEAC, B.P. 288, Yaoundé, Cameroonl; ${ }^{2}$ Vector Taxonomy Laboratory, ORSTOM, B.P. 5045, 34032 Montpellier, France

Keywords: malaria, vector, Anopheles funestus, bionomics, Cameroon

The earliest studies on the bionomics of Anopheles in Cameroon were carried out some 40 years ago (ADAM, 1956; MOUCHET \& GARIOU, 1961; MOUCHET, 1962). These studies showed that $A$. nili and $A$. moucheti were the principal malaria vectors in the rural forested areas of the country. Although $A$. gambiae s.l. was present, it had a minor role in malaria transmission in those areas. Very low densities of $A$. funestus were reported (LIVADAS et al., 1958), indicating the limited epidemiological importance of this vector; hence, its bionomics in the forested zone were not well known. Recent studies on malaria vectors and transmission dynamics in the rural areas of southern Cameroon have confirmed these observations (CARNEVALE et al., 1992; NJAN NLOGA et al., 1993; MANGA et al., 1995). The discovery of high densities of $A$. funestus in some villages in the forested zone made it possible for the bionomics of this species to be clarified, and its involvement in malaria transmission in those villages to be studied.

Etoa, Simbock and Nsimalen are villages near Yaoundé, the capital city of Cameroon. They are irrigated by 2 rivers, Biyeme and Mefou, which flow through a network of swamps. The swampy areas of the villages are separated by about $100 \mathrm{~m}$. The vegetation is semideciduous equatorial forest, and the climate is guinean with 2 rainy seasons and 2 dry seasons per year; the annual rainfall is about $1700 \mathrm{~mm}$.

Mosquito larvae were searched for along the Biyeme and Mefou rivers banks, in the swamps, and in pools. Anopheles larvae collected were reared separately to the adult stage and then identified. Indoor, all-night catches on human bait were made at Etoa twice a month for 4 months, from February to May 1996 (from the end of the long dry season to the end of the short rainy season). The Anopheles mosquitoes collected were identified and dissected to determine their physiological age and to search for Plasmodium sporozoites. The gonotrophic cycle was studied in June 1996, during the short rainy season, and its duration was determined using the following mark-recapture technique. For 3 consecutive nights, blood-fed mosquitoes were caught on human bait, marked with fluorescent powder (a different colour was used each night), and then released inside the dwellings. The duration of stage I (the period between egg laying and taking the next blood meal) was evaluated by examining follicle relics. The length of stage II (from blood meal to maturation of the oocytes) was determined by performing a series of delayed dissections; the oocyte stages were classified according to CHRISTOPHERS (1911).

At Etoa, $A$. funestus larvae were collected from the small grassy bays in the Biyeme and Mefou rivers. Of 78 adults that were identified, $38(49 \%)$ were $A$. finestus; the other species present were $A$. nili and $A$. moucheti. At Simbock, $A$. funestus were collected in smaller numbers: 4 specimens $(6.5 \%)$ were collected from the Mefou river, again with $A$. moucheti and $A$. niti. $A$. funestus was also collected from the swamps togerher with $A$. obscurus and $A$. namibiensis. This is the first record of $A$. namibiensis from Cameroon. At Nsimalen, $A$. funestus was found in the Mefou river, once again together with $A$. moucheti and $A$. nili, mainly (in large numbers) in a weedy pool with $A$. namibiensis. A. funestus bred in a variety of sites: rivers (like $A$. nili and $A$. mouchetr), swamps and pools. The presence of vegetation (not always erect) seemed to be the common factor in all these breeding sites.

A total of 913 mosquitoes was caught indoors at night at Etoa. Anopheles spp. formed $97 \cdot 3 \%$ of this sample, and A. funestus constituted $71 \cdot 2 \%$ of the Anopheles collected. The other Anopheles species were $A$. nili, $A$. moucheti and $A$. gambiae s.l. The average biting rate was 31.7 bites per person per night for all species of Anopheles, with an average of $22 \cdot 6$ for $A$. fimestus.

A. funestus had a parity rate $83 \cdot 1 \%$ (among 243 dissections) and its sporozoite index was $3 \cdot 27 \%$ (336 dissections). The average entomological inoculation rate was 1.3 infective bites per person per night, representing 41 infective bites per person per month. A. finnestus was responsible for $55 \%$ of these bites $(0.7 /$ night $)$, while the 3 other species shared the remaining $45 \%$. These findings led to the conclusion that $A$. funestus could be considered as a major local vector of malaria in forested areas, together with $A$. nili and $A$. moucheti.

A total of $158 \mathrm{~A}$. funestus was marked and released, and 2 were recaptured the second night after release (a recapture rate of $1.3 \%$ ). Thus, the duration of the gonotrophic cycle could be about 48 h. Dissection of 36 unfed female mosquitoes showed that $48 \%$ of them still had open follicle sacs, $36 \%$ had partially contracted follicle sacs, and only $17 \%$ had their follicle sacs completely contracted.

These findings indicated that most females took their next blood meal a few hours after egg laying. Twelve hours after the blood meal, 7 of $12 \mathrm{~A}$. funestus had oocytes in stage III; at $24 \mathrm{~h}, 6$ of 25 mosquitoes had oocytes at the beginning of stage IV; at $36 \mathrm{~h}, 60 \%$ (of a total of 33) had oocytes at stage $\mathrm{V}$; and at $40 \mathrm{~h}$, the maturation of the ovaries was complete: all 17 mosquitoes examined were at stage $V$. The duration of the gonotrophic cycle of $A$. funestus was therefore similar in the forested zone and in the savannah (BRENGUES \& $\mathrm{COZ}$, 1973).

\section{Acknowledgements}

This study was carried out with the technical support of Marc Nkou, Ivette Bella, Simon Mbingue and Marc Ngollo, from the Higher Teachers' Training College (ENS), Cameroon. It was funded by the French Ministry of Co-operation.

\section{References}

Adam, J. P. (1956). Note faunistique et biologique sur les anophèles de la région de Yaoundé et la transmission du paludisme en zone forestière du sud Cameroun. Bulletin de la Société de Pathologie Exotique, 49, 210-220.

Brengues, J. \& Coz, J. (1973). Quelques aspects fondamentaux de la biologie d'Anopheles gambiae Giles (sp. A) et d'Anopheles fimestus Giles, en zone de savane humide de l'Afrique de l'Ouest. Cuhiers ORSTOM, Série Entomologie Médicale et Parasitologie, 11, 107-126.

Carnevale, P., Le Goff, G., Toto, J. C. \& Robert, V. (1992). Anopheles nili as the main vector of human malaria in villages of southern Cameroon Medical and Veterinary Entomology, 6, $135-138$.

Christophers, R. (1911). The development of egg follicles in anophelines. Paludisme, 2, 73-88.

Livadas, G., Moucher, J., Gariou, J. \& Chastang, R. (1958). Peut-on envisager l'éradication du paludisme dans la région forestière du Cameroun? Actes du VI Congrès de Médecine Tropicale et du Paludisme, Lisbonne, pp. 230-255.

Manga, I., Toto, J. C. \& Carnevale, P. (1995). Malaria vectors and transmission in an area deforested for a new international airport in southern Cameroon. Annales de la Société Belge de Médecine Tropicale, $75,43-49$.

Mouchet, J. (1962). Influence des fleuves sur la biologie $\mathrm{d}^{\prime}$ Anopheles gambiae pendant la saison sèche dans le sud du
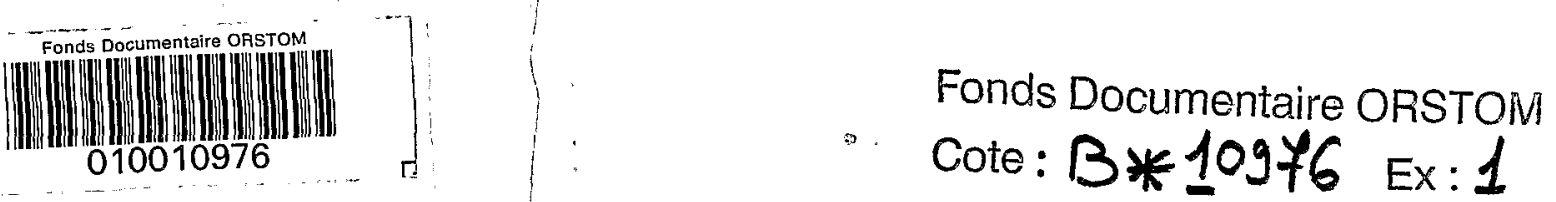
Cameroun. Bulletin de la Société de Pathologie Exotique, 55, 1163-1171.

Mouchet, J. \& Gariou, J. (1961). Répartition géographique et écologique des anophèles au Cameroun. Bulletin de la Société de Pathologie Exotique, 34, 102-118.

Njan Nloga, A., Robert, V., Toto, J. C. \& Carnevale, P. (1993). Anopheles moucheti, vecteur principal du paludisme au Sud-
Cameroun. Bulletin de Liaison et de Documentation de l'OCEAC, 26, 63-67.

Received 6 Fanuary 1997; revised 26 Febrtuary 1997; accepted for publication 27 February 1997

\section{Announcements}

\section{ROYAL SOCIETY OF TROPICAL MEDICINE AND HYGIENE Prizes}

\section{Undergraduate Project Prize}

The Royal Society of Tropical Medicine and Hygiene offers an annual prize of $£ 200$ for an account of work carried out in a tropical or developing country by a non-medical student of any nationality. The work will add to the knowledge of human or veterinary health or hygiene in the broadest sense. Particular attention will be directed towards originality and quality in the award of the prize. It is anticipated that the prize will act as a stimulus for the pursuit of excellence in research carried out by undergraduates.

\section{Medical Student Elective Prize}

The Royal Society of Tropical Medicine and Hygiene offers an annual prize of $f 200$ for an account of work carried out by a medical student of any nationality during an elective period spent in a tropical or developing country. In awarding this prize emphasis will be laid on the originality of the work and on its contribution to knowledge or understanding of tropical diseases.

Rules

1. Two prizes of $£ 200$ may be awarded annually in recognition of outstanding projects which increase knowledge of tropical medicine and hygiene in the broadest sense.

2. Candidates shall be nominated by their head of department, supervisor or Dean, with a supporting statement of up to 500 words.

3. The closing date for receipt of project reports is 31 December. The project should have been done or completed in the previous twelve months.

4. A Committee of three shall choose the prize winners.

5. The announcement of the prize winners will be made at the March meeting of the Society.

6 . The prizes will be presented by the President of the Society at the Annual General Meeting in June or July.

Please note that the Society cannot provide funds to cover students' elective travel expenses.

Application forms may be obtained from the Administrator, Royal Society of Tropical Medicine and Hygiene, Manson House, 26 Portland Place, London, W1N 4EY, UK.

\section{ROYAL SOCIETY OF TROPICAL MEDICINE AND HYGIENE Manson, Chalmers and Mackay Medals 1998}

The Manson Medal is awarded triennially. It is the Society's highest mark of distinction, and shall be made to the person whose contribution to any branch of tropical medicine is considered by Council to merit the honour most.

The Chalmers Medal is awarded each year in recognition of research contributing to the knowledge of tropicalmedicine or tropical hygiene. Only persons of 45 years or under on 1 June of the year of the award shall be eligible.

The Donald Mackay Medal is awarded for outstanding work in tropical health, especially relating to improvement in the health of rural or urban workers in the tropics.

Nominations may be made by any Fellow of the Society, on forms available from Manson House. Completed forms should be sent to the Honorary Secretaries by 31 October 1997. For full details please refer to the Yearbook. 


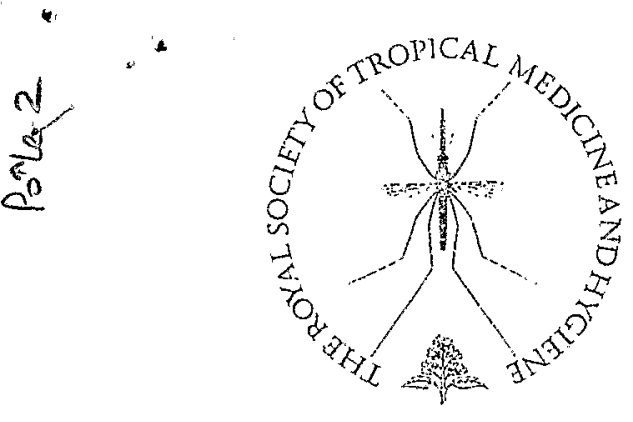

Vol. 91 No,, $\mathrm{pp} .369-496$

July-August 1997

ISSN $0035-9203$

Zonae Torridae Tutamen

\section{Transactions of the}

Royal Society of

Tropical Medicine and Hygiene

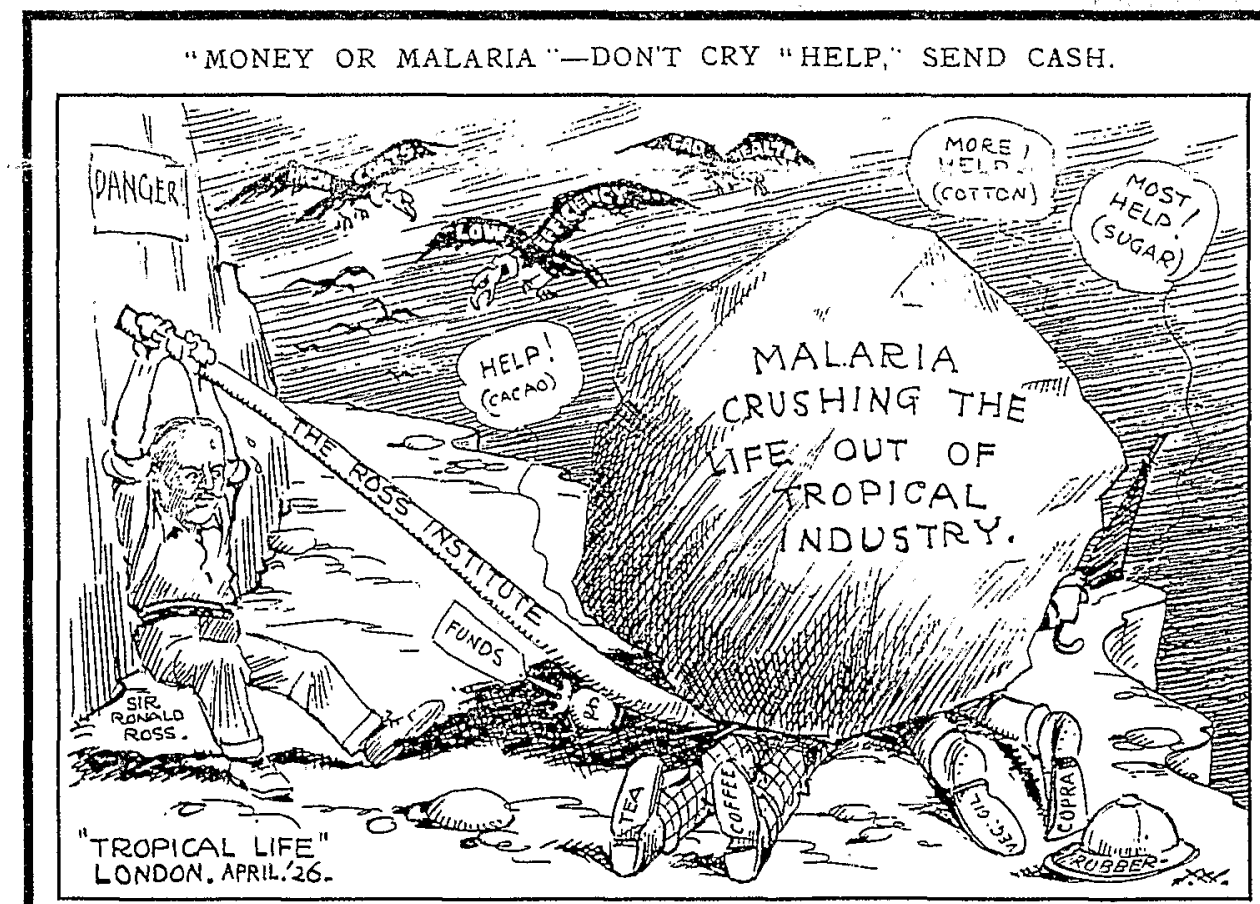

Wanted-A Bigger Fulcrum. One Ten Times the Present Size Preferred.

Royal Sociery of Tropical Medicine and Hygiene,

Manson House, 26 Portland Place,

London, WIN $4 E Y$, UK

Telephone: +44 (0)1715802127

Fax: +44 (0)171 +361389

e-mail: mail@rstmh.org

$P M \cdot 80$

: Her Majesty the Queen

$=1$ SEP, 192

Soutt 